\title{
Developing and Implementing Instrumentation for Digital High School Curricula: A Regional Study of a Rubric for Instructional Quality
}

\author{
By Rachel Vannatta Reinhart* \\ Savilla Banister ${ }^{\dagger}$
}

\begin{abstract}
As our world has continued to become more dependent on digital communication and collaboration, online learning environments have become more sophisticated. Demand for online and/or hybrid learning materials has increased, not only in higher education arenas, but in elementary and secondary schools, as well. This study describes the development and implementation of an evaluative rubric for high school digital curricula created for a United States regional consortium of school districts, charged with expanding quality digital learning environments for their students. Digital instructional units for ten high school courses were created by collaborative teacher design teams, with each team consisting of 4-7 teachers. With the goal of creating 1/3 of a year's curriculum, teams developed 2-4 units per course in the first year. A total of 30 units were developed and evaluated. In collaboration with project partners, developed the NWOi3 Evaluation Rubric for Digital Curriculum that was used to assess curriculum units and consisted of 36 criteria organized by eight areas: 1) Overview, 2) Learning Targets, 3) Instructor Support, 4) Accessibility, 5) Instructional Materials, 6) Learner Interaction and Engagement, 7) Technology, and 8) Assessment. A variety of sources contributed to rubric development: Quality Matters K-12 Secondary Rubric (Quality Matters, 2017), Blended Course Peer Review Form (Blended Learning Toolkit, 2014), and the National Standards for Quality Online Programs (International Association for K-12 Online Learning [iNACOL], 2011). The evaluation process utilized a team of reviewers: five content experts, and three curriculum/ technology experts. A third evaluator then summarized the two reviews for every unit, providing a score for each criterion along with detailed comments and feedback. The process of how rubric results were analyzed and reported is described along with the challenges encountered.
\end{abstract}

Keywords: blended learning, curriculum development, evaluation, Teacher design teams, rubrics.

\section{Introduction}

As a part of the public critique of government spending in the United States, the expense associated with the purchase of textbooks for K-12 and university classes has been under scrutiny (Harris \& Schneegurt, 2016). In response to this controversy, schools have begun to explore digital options for academic materials, including Open Source alternatives (Delimont, Turtle, Bennett, Adhikari, \& Lindshield, 2016; Fischer, Hilton, Robinson, \& Wiley, 2015; Hilton, 2016; Prasad

*Professor, Bowling Green State University, USA.

†Professor, Bowling Green State University, USA. 
\& Usagawa, 2016). Accompanying this transition, the interest of expanding the impact and usefulness of digital resources that move beyond mere textual content to more media-rich and interactive learning materials has grown (Lombardi et al., 2017; Matuk, Linn, \& Eylon, 2015). There are certainly reservations about immersing students in a completely digital learning environment (Dobler, 2015; Duffy \& Ney, 2015; Toppin \& Toppin, 2016), giving rise to a more balanced vision of blending learning experiences (Mirriahi, Alonzo, \& Fox, 2015).

In an effort to reduce the continuous textbook expenses and provide students with dynamic, digital learning resources, the NorthWest Ohio Innovate, Instruct, and Inspire (NWOi3) consortium of seven school districts set out to develop ten digital courses for high school: Geometry, Algebra 1, Algebra 2, English 9, English 10, English 11, Biology, Physical Science, American History and American Government. Although curricula were designed to be delivered through a digital interface, participating districts planned to continue instruction in a faceto-face environment that utilizes a blended learning approach. As a means of both guiding curriculum development and evaluating its quality, the NWOi3 Digital Curriculum Rubric was created and implemented. Jonnson and Svingby (2007) suggest that analytic rubrics may enhance performance as well its scoring reliability. This paper describes the process of curriculum development and instrument created to evaluate curriculum quality.

\section{Literature Review}

Prioritizing dynamic digital learning environments in lieu of traditional textbooks, and focusing on the creation of meaningful blended learning venues for K-12 students has caused school administrators and teachers to abandon vendor options for locally-crafted resources (Levitt, 2016; Marco-Bujosa, McNeill, González-Howard, \& Loper, 2017; Marsh, 2015; Naeini \& Shakouri, 2016). In some instances, school districts or entire regions have banded together to create elearning course materials for identified curricular areas. Selecting a space to house these assets has been one hurdle to overcome, as many K-12 schools have not adopted a robust learning management system. In addition, determining the quality of e-learning resources is a major concern as materials are developed and deployed. Establishing criteria for the evaluation of these teacher-created, digital curricular elements has now become a significant focus for school districts (Adair \& Shattuck, 2015; Legon, 2015; Snodgrass Rangel, Bell, Monroy, \& Whitaker, 2015). Jonsson and Svingby (2007) indicate that the use of an analytic, topicspecific rubric can enhance reliable scoring of performance assessments and promote learning since a rubric clarifies the expectations and facilitates feedback and self-assessment.

Although several organizations have published standards and/or guidelines for such online curricular endeavors in an attempt to guide and evaluate quality, most early approaches (BlackBoard, Quality Matters) applied to stand-alone online courses and/or online programs. Not until 2011 when the BlendKit Reader was initially released, did guidelines begin to address the unique aspects of blended 
courses. Since that time, several institutions-University of Massachusetts Dartmouth, University of Wisconsin Milwaukee, and Penn State - have developed quality benchmarks for blended courses but often with a particular emphasis, such as formative evaluation, blended design, technology use (Blended Learning Toolkit, 2014). In response to the blended learning movement, other organizations began to revise online standards to incorporate a blended approach. After an extensive review of various online and blended course standards, three sets of standards guided the development of the NWOi3 rubric: National Standards for Quality Online Courses (iNACOL, 2011), Quality Matters K-12 Secondary Rubric (Quality Matters, 2017), and the Blended Course Peer Review Form (Blended Learning Toolkit, 2014). Although the instruments developed by Quality Matters and iNACOL originally focused on online courses, more recent versions incorporated blended learning. A comparison of these three instruments is presented in Table 1. Ranging from 36 to 42 criteria, these sets of standards varied in structure and evaluation rating scale. Quality Matters measured nine areas that required the collaborative agreement of the fulfillment of essential criterion (those weighted 3). In contrast, the guidelines produced by iNACOL evaluated five areas and applied a five-point scale. Finally, the 2014 Blended Learning Toolkit measured five areas and utilized a qualitative rating scale.

Table 1. Comparison of Quality Online/Blended Course Standards

\begin{tabular}{|c|c|c|c|}
\hline Rubric & Quality Matters & iNACOL & $\begin{array}{c}\text { Blended Learning } \\
\text { Toolkit }\end{array}$ \\
\hline \# of Criteria & 41 & 42 & 36 \\
\hline $\begin{array}{l}\text { Organizational } \\
\text { Structure }\end{array}$ & $\begin{array}{l}\text { - Course Overview \& } \\
\text { Introduction } \\
\text { - Learning Objectives } \\
\text { - Assessment \& } \\
\text { Measurement } \\
\text { - Instructional } \\
\text { Materials } \\
\text { - Course Activities \& } \\
\text { Learner Interaction } \\
\text { - Course Technology } \\
\text { - Learner Support \& } \\
\text { - Accessibility \& } \\
\text { - Csability } \\
\text { - Compliance } \\
\text { Standards }\end{array}$ & $\begin{array}{l}\text { - Content } \\
\text { - Instructional Design } \\
\text { - Student Assessment } \\
\text { - Technology } \\
\text { - Course Evaluation } \\
\text { \& Support }\end{array}$ & $\begin{array}{l}\text { - Course } \\
\text { Expectations } \\
\text { - Learning Objectives } \\
\text { - Learning Activities } \\
\text { \& Content } \\
\text { - Learning } \\
\text { Assessments } \\
\text { - Technology Tools } \\
\text { - Ethical \& Legal } \\
\text { Compliances } \\
\text { - Implementation of } \\
\text { Blended Course }\end{array}$ \\
\hline Rating Scale & $\begin{array}{l}\text { Collaborative } \\
\text { evaluation to } \\
\text { determine fulfillment } \\
\text { of criteria. Criteria are } \\
\text { weighted from 1-3. 3- } \\
\text { point criteria are } \\
\text { essential and must be } \\
\text { fulfilled. }\end{array}$ & $\begin{array}{lr}\text { 5-point } & (0-4) \\
\text { satisfaction } & \text { scale } \\
\text { ranging from } & \text { Absent } \\
(0) \quad \text { to } & \text { Very } \\
\text { Satisfactory (4) } & \end{array}$ & $\begin{array}{l}\text { Five level qualitative } \\
\text { implementation scale } \\
\text { ranging from Missing } \\
\text { to Exemplary. }\end{array}$ \\
\hline
\end{tabular}




\section{The Project}

Initially funded through an Ohio Straight A Grant, the NWOi3 Project spanned three years and involved extensive teacher training, digital exploration, curriculum development and revision. Ten collaborative Design Teams of 43 master teachers participated in professional development training in the critical areas of best practices for the development and integration of digital learning; content specific digital learning tools and techniques; and assessment literacy, as well as general and subject-specific curriculum design. Most training and development was conducted over three summers. Each year, teams were required to develop one-third of a course's curriculum so that a course would be complete at the end of three years. Each Design Team, consisting of 4-7 teachers, developed digital curriculum for one of the ten core high school courses. With the goal of creating $1 / 3$ of a year's curriculum, teams developed 2-4 units per course. Typically a given unit was developed by one or two individuals. A total of 30-36 units were developed and evaluated each year.

Developing common digital curriculum across seven school districts presented numerous challenges. First, the participating districts differed on several factors: size (small, medium, large); location (urban, suburban, rural); technology richness (teacher training, one-to-one, Learning Management System); financial resources (growth versus decline). The size of the Consortium and the many differences across districts had several implications for curriculum development.

- Curriculum Storage-Digital curriculum had to be housed in a free, accessible, and secure location. Since the purchase of a common LMS was not feasible, a Google site was created in which each course had a folder that could be organize its curricular units. In an attempt to mimic an LMS, teacher units and parallel student units were developed. A standard framework for curriculum was applied across courses and units within the Google site.

- Technology access - Since access varied across districts, curriculum was developed to support various levels of technology integration (one-to-one, teacher computer only). Design Teams were told to assume a one-to-one environment was present but supply options for a low-tech environment. In addition, all curriculum materials had to be accessible across the Consortium districts. Therefore, participating districts agreed on several purchased (e.g., Gizmos, Citelighter).

- Transferability-Although complete digital courses were developed and housed in the NWOi3 Google site, actual teacher and student use required server transfer of each file to another site - a very tedious process.

\section{NWOi3 Evaluation Rubric for Digital Curriculum}

Hired as the project external evaluator, the Center of Assessment and Evaluation Services (CAES) at Bowling Green State University was charged with 
the task of evaluating the curricular units once they were completed. CAES, in collaboration with the NWOi3 leadership, created a rubric to not only evaluate the curricula, but also establish curricular standards, support professional development outcomes, and communicate project expectations. University/K-12 partnerships have been cited as an essential component in sustaining teacher collaborative design and innovation (Voogt, Laferriere, Breuleux, Itow, Hickey, \& McKenney, 2015).

The rubric (see Appendix A) consisted of 36 criteria organized by eight areas: 1) Overview, 2) Learning Targets, 3) Instructor Support, 4) Accessibility, 5) Instructional Materials, 6) Learner Interaction and Engagement, 7) Technology, and 8) Assessment. Each criterion was evaluated using a 4-point scale: $0=$ Missing (no evidence), 1=Incomplete (fair start, but only partial implementation), 2=Promising (good start, but lacking some aspects), 3=Accomplished (excellent implementation).

The Leadership team also developed unit and lesson plan templates to guide the organizational structure of the curriculum and support fulfillment of the NWOi3 Evaluation Rubric of Digital Curriculum. Since the newly developed curriculum was to be implemented across the seven participating districts and a multitude of teachers, teacher implementation guidelines needed to be very specific. Similar to textbooks, Design Teams were writing both the student and teacher versions for each course. Templates and rubrics were disseminated during the first week of professional development training. The first round of curriculum development occurred over a 10-week period during the summer.

The evaluation process utilized a team of reviewers: five content experts, and three curriculum/technology experts. Reviewers were trained on the criteria and practice reviewing with two nearly completed units. Since units were not complete, reviewer training could not include the establishment of criterion norms. In the first year, 30 units were developed. Each unit was reviewed by one content expert and one curriculum/technology expert. A third evaluator then summarized the two reviews for every unit, providing a score for each criteria along with detailed comments and feedback. This third evaluator reviewed all 30 units to ensure consistency in criteria interpretation and reporting.

While the primary goal of the project was to develop digital curriculum for the ten core courses, the NWOi3 Leadership Team was very deliberate in not providing a detailed curriculum model for Design Teams. The rationale for this decision was two-fold. First, due to the innovative nature of the project, an appropriate model was not found. Second, providing a model may limit Design Teams in their creativity and innovation. As such, beyond the professional development training and open work sessions, Design Teams received the Unit Template and the Evaluation Rubric for Digital Curriculum as guides. Design Teams also met with a CAES evaluator at least once during an open work session, to receive formative feedback on their curriculum units. 


\section{Implementing the NWOi3 Evaluation Rubric for Digital Curriculum}

Design Teams completed curriculums in early August of each year. CAES had approximately one month to complete all evaluations and submit feedback to the teams for revision. Since each course consisted of 3-4 units, which were reviewed by two reviewers, each reviewer evaluated a minimum of six units. Several challenges arose in the review process.

\section{Reviewer Reliability}

Reviewer fatigue was a challenge since each unit took approximately two hours. The time commitment was overwhelming and tiring. Next, reviewers struggled to grasp all 36 criteria. For example, content experts were comfortable in examining the breadth and depth of content, they were not necessarily knowledgeable in evaluating transformational technology use. Although, reviewers had participated in rubric training; it was very clear at the onset that reviewers were interpreting criteria differently. These issues necessitated a third reviewer (not originally planned) to combine and mediate the two reviews.

\section{The Quality Standard: Criterion versus Normative}

Obviously the NWOi3 Rubric was meant to evaluate the fulfillment of criterion. However, the evaluation process soon revealed a gaping range in curriculum quality. A unit that was initially rated as fairly average, later looked exemplary after evaluating a poorly developed unit. At some point in the evaluation process (typically after examining a stellar unit), reviewers transitioned to a normative comparison for each criterion.

\section{Feedback: How much is enough?}

Feedback on 36 criteria was overwhelming for both the evaluator and the recipient. While the evaluation team sought to provide valid and reliable feedback on each unit, poorly developed units were devastingly low scoring. Fearing that participating teachers may drop the project after receiving such negative feedback, the leadership team asked the reviewers to prioritize criteria in an effort to provide more focused and constructive feedback.

\section{Reporting Evaluation Results}

After all 30 units were reviewed and summarized, a review summary for each unit was submitted to the Leadership Team, who then shared the results with each Design Team. The review summary averaged the two reviewer scores for each criterion and provided recommendations for improvement by criterion. CAES also presented a summary report that included a table of Course scores and overall means for each criterion (not included due to length). This allowed for course comparison by criterion as well as identification of low score criterion. Eleven low 
scoring criterion (less than 2.0) were identified and are presented in Table 2. The area of Assessment was in most need for improvement, followed by Technology and Instructor Support.

Table 2. Summary of Low Scoring Criteria

\begin{tabular}{|c|c|c|}
\hline Area & Criteria & $\begin{array}{c}\text { Overall } \\
\text { Mean }\end{array}$ \\
\hline Assessment & $\begin{array}{l}\text { 8.7 Models Next Generation or PARCC assessments } \\
\text { (technology and question design) }\end{array}$ & 0.8 \\
\hline $\begin{array}{l}\text { Instructional } \\
\text { Materials }\end{array}$ & $\begin{array}{l}\text { 5.5 Instructional materials provide strategies for } \\
\text { differentiation, intervention, and } \\
\text { enrichment/extension. }\end{array}$ & 1.4 \\
\hline Assessment & $\begin{array}{l}\text { 8.6 Performance assessments have rubrics with } \\
\text { detailed, descriptive criteria for the evaluation of } \\
\text { students' work. }\end{array}$ & 1.4 \\
\hline $\begin{array}{l}\text { Learner } \\
\text { Interaction \& } \\
\text { Engagement }\end{array}$ & $\begin{array}{l}\text { 6.4 The requirements for student interaction are } \\
\text { clearly articulated. }\end{array}$ & 1.5 \\
\hline Technology & $\begin{array}{l}7.4 \text { Technology used to support a transformational } \\
\text { learning environment (creates new tasks } \\
\text { previously inconceivable without technology). }\end{array}$ & 1.5 \\
\hline Assessment & $\begin{array}{l}8.4 \begin{array}{l}\text { Formative assessments provide students with } \\
\text { descriptive feedback and an opportunity to reflect } \\
\text { on progress. }\end{array} \\
\end{array}$ & 1.5 \\
\hline Assessment & $\begin{array}{l}\text { 8.2 Assessment strategies and student expectations are } \\
\text { clearly defined. }\end{array}$ & 1.6 \\
\hline $\begin{array}{l}\text { Instructor } \\
\text { Support }\end{array}$ & $\begin{array}{l}3.1 \text { Unit/lesson plans offer guidance on instructor } \\
\text { implementation. }\end{array}$ & 1.8 \\
\hline $\begin{array}{l}\text { Instructor } \\
\text { Support }\end{array}$ & $\begin{array}{l}\text { 3.2 Instructions describe how technology is used and } \\
\text { provide recommendations on how to adapt for } \\
\text { various technology settings. }\end{array}$ & 1.8 \\
\hline Technology & $\begin{array}{l}\text { 7.3 Technology tools and media support student } \\
\text { engagement and guide the student to become an } \\
\text { active learner. }\end{array}$ & 1.8 \\
\hline Assessment & $\begin{array}{c}\text { 8.5 Summative assessments evaluate multiple } \\
\text { cognitive levels (Bloom's, Webb, Hess). }\end{array}$ & 1.8 \\
\hline
\end{tabular}

NWOi3 Leadership met with BGSU to discuss revision priorities and communication methods with Design Teams. Because of the limited time to revise, NWOi3 Leadership decided to focus on the overall goal of creating more consistency and specificity across the units so that units would be more userfriendly for both teachers and students. As a result, the following priorities were identified: 
- Organization and format

$\circ$ Apply a consistent format and structure across the units in your course.

- Move all documents to the NWOi3 site and out of your Google drive.

- Make sure all links work and all content is accessible!

- Try to embed links within the lesson steps (for both teachers and students).

- Teacher Guidance and Support

$\circ$ Unit plans should present an overview of the lessons, how technology is being used, and the overall assessment plan for the unit. A bulleted list is fine.

- Differentiation

- Be more specific in how Blendspaces could be used for differentiation. Provide guidance to both teachers and students.

- Assessment

- Clarify how results from formative assessments will be used to guide instruction and facilitate student reflection on progress.

Table 3. Model Units Exemplifying Targeted Revisions

\begin{tabular}{|c|c|c|}
\hline Characteristic & Unit & $\begin{array}{l}\text { Explanation } \\
\end{array}$ \\
\hline \multirow{2}{*}{$\begin{array}{l}\text { Organization \& } \\
\text { Guidance }\end{array}$} & Algebra 1 -Unit 8 & $\begin{array}{l}\text { Unit plan provides an excellent overview } \\
\text { of the unit lessons, the technology utilized } \\
\text { in each lesson, and the assessments } \\
\text { throughout the unit. }\end{array}$ \\
\hline & $\begin{array}{l}\text { English 11-Dark } \\
\text { Romanticism }\end{array}$ & $\begin{array}{l}\text { This unit utilizes a great lesson plan } \\
\text { format that provides detailed guidance on } \\
\text { assessments and lesson implementation. }\end{array}$ \\
\hline Active Learning & English 10 -Unit 2 & $\begin{array}{l}\text { A very student-centered unit in which } \\
\text { students are developing and teaching } \\
\text { lessons on short stories! }\end{array}$ \\
\hline \multirow[b]{2}{*}{ Tech Tools } & Geometry-Unit 3 & $\begin{array}{l}\text { Blendspace provides a nice mix of videos, } \\
\text { practice, and interactive applets. }\end{array}$ \\
\hline & $\begin{array}{l}\text { Biology-Units } 8 \& \\
9\end{array}$ & $\begin{array}{l}\text { Use of virtual labs, interactive simulations } \\
\text { and games has the beginnings of } \\
\text { transformation learning. }\end{array}$ \\
\hline \multirow[t]{2}{*}{ Differentiation } & $\begin{array}{l}\text { English 11-Dark } \\
\text { Romanticism }\end{array}$ & \multirow{2}{*}{$\begin{array}{l}\text { Most of the teacher lessons provide } \\
\text { specific recommendations for } \\
\text { differentiation. }\end{array}$} \\
\hline & Geometry_-Unit 3 & \\
\hline \multirow[t]{2}{*}{ Assessment } & English 10 -Unit 2 & $\begin{array}{l}\text { Unit plan presents overall assessment plan } \\
\text { throughout the lessons. Utilizes a variety } \\
\text { of assessments, presents directions and } \\
\text { rubrics for all performance assessments, } \\
\text { and indicates how formative assessment } \\
\text { results guide instruction. }\end{array}$ \\
\hline & $\begin{array}{l}\text { English } 11-\text { Dark } \\
\text { Romanticism }\end{array}$ & $\begin{array}{l}\text { This unit provides a great mix of } \\
\text { assessments (performance and objective). }\end{array}$ \\
\hline
\end{tabular}


In addition, model units were identified to guide revisions in specific areas (see Table 3). These model units were made available to all Design Teams so that they would better understand the curriculum expectations and the necessary level of quality. Project Managers met with each Design Team to discuss evaluation results for each unit. Finally, CAES sent Design Teams a video via email that helped focus revision efforts.

Based upon the evaluation results of curriculum units, the following broad conclusions were identified:

- Format, detail, and organization varied greatly across lessons, units, and courses.

- Innovative technology resources were identified but not adequately integrated into the lesson.

- Most lessons followed a traditional format, with the bulk of instruction being "presented" in class.

- Technology use for most lessons was at the substitution and augmentation levels.

- Formative assessments were not adequately developed or utilized.

\section{Discussion}

The NWOi3 Evaluation Rubric for Digital Curriculum provided an excellent framework for the development and evaluation of quality technology-rich curriculum. The rubric provided detailed feedback for revision. However, the enormity and complexity of curriculum development and the rubric used to evaluate it were extremely difficult for all (Design Teams, reviewers, Leadership Team) to comprehend and apply. The participating high school teachers were so focused on content and most comfortable with their day-to-day traditional teaching practices that they struggled to develop innovative curriculum on both macro (considering the full year) and micro (addressing all the details) levels. Much research reveals that teachers are often ill-prepared for the demands of curriculumdeveloper as well working with the structure of a collaborative design team (Handelzalts, 2009; Ronfeldt, Farmer, McQueen, \& Grissom; 2015).

Similarly, reviewers also struggled with the rubric's complexity. The enormity of monitoring 36 criteria coupled with reviewer fatigue from evaluating numerous units possibly lead to issues of intra-rater reliability (inconsistency of one rater). In addition, inter-rater reliability (inconsistency across different raters) was likely an issue as well due to the various professional backgrounds and experiences of the evaluators. Although, individuals from various content areas were sought to serve as reviewers, these different perspectives likely contributed to different interpretations of criteria. While rubric training was conducted for the reviewers within a 3-hour session, the length was inadequate to fully explore the application of each criterion.

Although Leadership and Evaluation Teams met to reconsider the 36-criterion rubric, each criterion was deemed to guide an integral component of quality 
curriculum and instruction. When compared to the three rubrics--National Standards for Quality Online Courses (iNACOL, 2011), Quality Matters K-12 Secondary Rubric (Quality Matters, 2017), and the Blended Course Peer Review Form (Blended Learning Toolkit, 2014) — used as a basis for the NWOi3 Rubric, our rubric was on the low end of number of criterion. In the end, only slight clarifications were made to some of the criterion.

However, other adjustments were made in the second year to support the comprehension and fulfillment of the NWOi3 Rubric. Models were identified to communicate exemplary quality of several challenging criterion. Jonsson and Svingby (2007) indicate that providing exemplars not only increase scoring reliability but also quality performance. Similarly, Davis and Krajcik (2005) support the use of exemplary curriculum materials to help Teacher Design Teams better understand the expectations when developing curriculum. Training was also expanded for both Design Teams and reviewers. Design Teams received professional development on priority (low scoring) criterion-differentiation, assessment, transformational technology use. Reviewer training focused on highly variable criterion as well as low scoring criterion as a means of increasing reliability (Jonsson \& Svingby, 2007). Such training included the discussion on criterion content, quality ranges, exemplars, and inferior units.

As the primary author of NWOi3 Rubric and evaluator of the project, CAES served as an integral partner but also an external evaluator. At times this relationship created tension in the feedback process with teachers and the evaluation process with Leadership. However, Voogt et al. (2015) notes that such tension among university/school partnerships is critical in sustaining collaborative process and innovative development.

\section{Conclusions}

The NWOi3 Rubric has become the foundation of NWOi3 curriculum development, revision, and quality. Despite its complexity, the NWOi3 Rubric reflects the intricacies of the curriculum development process, product, and implementation. This rubric provided not only a target for curriculum quality but also a framework for evaluation and feedback (Jonsson \& Svingby, 2007), which was then used to guide training for further improvement. The unique university/K12 partnership facilitated a vehicle for growth and communication throughout the project (Voogt et al., 2015). While the authors recognize that each digital curriculum development project carries unique aspects and challenges, the NWOi3 Rubric may serve as a starting point for such endeavors.

\section{References}

Adair, D., \& Shattuck, K. (2015). Quality matters. American Journal of Distance Education, 29(3), 159.

Blended Learning Toolkit (2014). Retrieved from http://bit.ly/2BoITyQ.

Davis, E., \& Krajcik, J. (2005) Designing educative curriculum materials to promote 
teacher learning. Educational Researcher, 34(3), 3-14.

Delimont, N., Turtle, E. C., Bennett, A., Adhikari, K., \& Lindshield, B. L. (2016). University students and faculty have positive perceptions of open/alternative resources and their utilization in a textbook replacement initiative. Research in Learning Technology, 24(1), 29920-13.

Dobler, E. (2015). E- textbooks: A personalized learning experience or a digital distraction? Journal of Adolescent \& Adult Literacy, 58(6), 482-491.

Duffy, K., \& Ney, J. (2015). Exploring the divides among students, educators, and practitioners in the use of digital media as a pedagogical tool. Journal of Marketing Education, 37(2), 104-113.

Fischer, L., Hilton, J., Robinson, T., \& Wiley, D. (2015). A multi-institutional study of the impact of open textbook adoption on the learning outcomes of post-secondary students. Journal of Computing in Higher Education, 27(3), 159-172.

Handelzalts, A. (2009). Collaborative curriculum development in teacher design teams. University of Twente. Retrieved from http://bit.ly/2nlxuhm.

Harris, D., \& Schneegurt, M. A. (2016). The other open-access debate: Alternate educational resources need to be further developed to counteract an increasingly costly textbook burden on university students. American Scientist, 104(6), 334.

Hilton III, J. (2016). Open educational resources and college textbook choices: A review of research on efficacy and perceptions. Educational Technology Research and Development, 64(4), 573-590.

International Association for K-12 Online Learning. (2011). National Standards for Quality Online Teaching (v2). Retrieved from http://bit.ly/2gtBBmD.

Jonsson, A., \& Svingby, G. (2007). The use of scoring rubrics: Reliability, validity and educational consequences. Educational Research Review 2, 130-144.

Legon, R. (2015). Measuring the impact of the quality matters rubric ${ }^{\mathrm{TM}}$ : A discussion of possibilities. American Journal of Distance Education, 29(3), 166-173.

Levitt, M. (2017). Educators share 10 best teaching, technology practices. The Education Digest, 82(8), 56.

Lombardi, A. R., Izzo, M. V., Rifenbark, G. G., Murray, A., Buck, A., Monahan, J., \& Gelbar, N. (2017). The impact of an online transition curriculum on secondary student reading: A multilevel examination. Career Development and Transition for Exceptional Individuals, 40(1), 15-24.

Marco-Bujosa, L. M., McNeill, K. L., González-Howard, M., \& Loper, S. (2017). An exploration of teacher learning from an educative reform-oriented science curriculum: Case studies of teacher curriculum use. Journal of Research in Science Teaching, 54(2), 141-168.

Marsh, S. (2015). A model for leadership that improves learning: New insights for schools and scholars. Leadership and Policy in Schools, 14(1), 67-103.

Matuk, C. F., Linn, M. C., \& Eylon, B. (2015). Technology to support teachers using evidence from student work to customize technology-enhanced inquiry units. Instructional Science, 43(2), 229-257.

Mirriahi, N., Alonzo, D., \& Fox, B. (2015). A blended learning framework for curriculum design and professional development. Research in Learning Technology, 23(1), 28451-14.

Naeini, A. V., \& Shakouri, N. (2016). Preparing for a postmethod pedagogy: A transformative approach to curriculum development. Theory and Practice in Language Studies, 6(3), 586.

Prasad, D., \& Usagawa, T. (2014). Towards development of OER derived custom-built open textbooks: A baseline survey of university teachers at the University of the South Pacific. International Review of Research in Open and Distance 
Learning, 15(4), 226-246.

Quality Matters. (2017) Non-annotated Standards from the QM K-12 Secondary Rubric ( $4^{\text {th }}$ ed.). Maryland Online, Inc. Retrieved from http://bit.ly/2jBtggt.

Ronfeldt, M., Farmer, S. O., McQueen, K., \& Grissom, J. A. (2015). Teacher collaboration in instructional teams and student achievement. American Educational Research Journal, 52(3), 475-514.

Snodgrass Rangel, V., Bell, E. R., Monroy, C., \& Whitaker, J. R. (2015). Toward a new approach to the evaluation of a digital curriculum using learning analytics. Journal of Research on Technology in Education, 47(2), 89-104.

Toppin, I. N., \& Toppin, S. M. (2016). Virtual schools: The changing landscape of K-12 education in the U.S. Education and Information Technologies, 21(6), 1571-1581.

Voogt, J., Laferriere, T., Breuleux, A., Itow, R. C., Hickey, D. T., \& McKenney, S. E. (2015). Collaborative design as a form of professional development. Instructional Science, 43(2), 259-282. 


\section{Appendix}

\section{NWOi3 Evaluation Rubric for Digital Curriculum}

\begin{tabular}{|c|c|c|}
\hline \multicolumn{3}{|r|}{ Evaluation Scale } \\
\hline 3 & Accomplished & $=$ excellent implementation \\
\hline 2 & Promising & good implementation, but lacking some aspects \\
\hline 1 & Incomplete & fair start, but only partial implementation \\
\hline 0 & Missing & no evidence \\
\hline NA & Not Applicable & \\
\hline
\end{tabular}

5

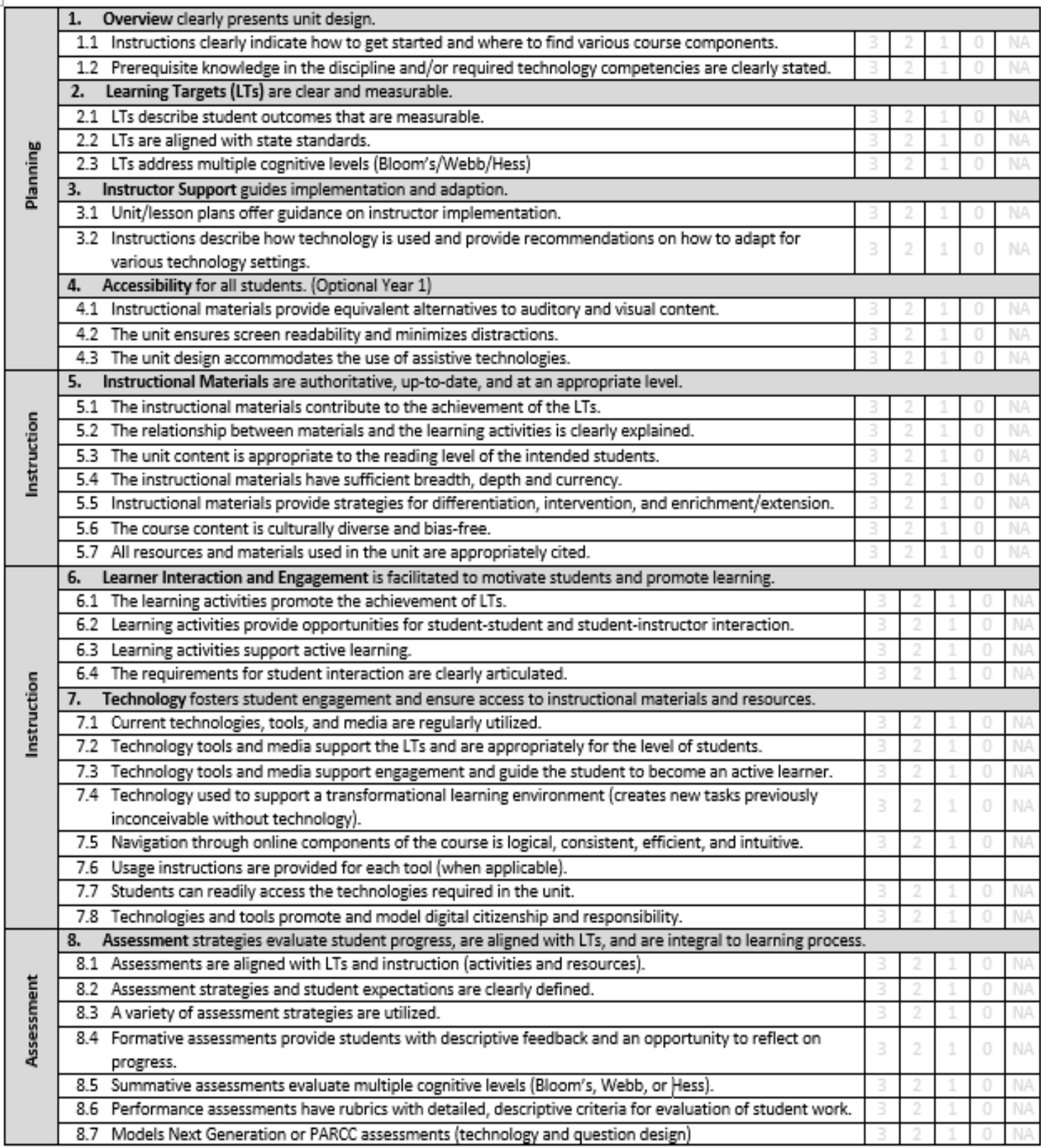


